\title{
Ethnic Diversity and Federation of Pakistan: A Societal Perspective
}

\author{
Tariq Anwar Khan*1-2, Adil Khan ${ }^{3} \&$ Muhammad Imran Mehsud ${ }^{2-4}$ \\ 1. Department of Political Science, Faculty of Social Science, University of Punjab, Lahore, Pakistan. \\ 2. Department of Political Science \& International Relations, Hazara University, Mansehra, Pakistan. \\ 3. Department of Pakistan Studies, Faculty of Social Sciences, Hazara University, Mansehra, Pakistan. \\ 4. School of Politics \& International Relations, Quaid-e-Azam University, Islamabad, Pakistan.
}

\begin{abstract}
This paper aims to identify the factors responsible for reluctance of centre to decentralise power and imitation of the same trend in provinces while dealing with minority ethno-lingual identities. The paper explores questions: what is the nature of federalism in Pakistan? How federal question is dealt in the three constitutions of the republic? How differently ethnic groups responded to various federal arrangements orchestrated by the managers of the state over the years? Objectives of the study are to develop an understanding into the challenges posed to federalism in Pakistan and to develop a more inclusive approach for addressing the federal question. The discussion generated in this study is based upon qualitative analysis of existing published literature in the form of books, research articles, reports, and official documents. The narrative upon which the federation of Pakistan has been constructed is self-contradictory. The paper not only exposes the contradictions of this narrative but also includes societal perspective on the ethnic diversity and federation of Pakistan. It has been concluded that the crisis generated by over-centralisation of the state could only be resolved by ensuring the fundamental federal values like decentralization, provincial autonomy, and devolution within the provinces to the grass root level.
\end{abstract}

Keywords: Centralisation of Power, Devolution of Power, Decentralisation of Power, Ethnic Politics, Ethno-Lingual Identities, Identity Politics, Federalism.

\section{Introduction}

Federation is a concept linked with the democratization of heterogeneous societies under a central government characterised by a union of partially self-governing units. Where democratization led to the representative governments, emergence of citizenship and contest of economic and political rights, it also contributed to genesis of group consciousness among sub-national entities and their struggle for gaining more political and economic opportunities, in comparison to each other, and for devolution and decentralization of power, against the central government (Naazer et al, 2017). Federal structure is a response to accommodate these sub-national entities in the broader national system and to manage emerging socio-political, economic and identity conflicts among them. Thus, fundamentally the federalist ideas surround the issues of sub-national autonomy and the range and extent of power devolution to these units. Although, the institutional arrangements to develop operational political structures upon federalist ideas differ from state to state yet the foundational narrative of all federations is same i.e., acceptance of sub-national identities. 
Federalist ideas in the subcontinent were introduced during colonial period keeping in view the heterogeneity of the society. All India Muslim League (AIML) during the last phase of colonial period emerged as a party standing out for the rights of sub-national identities, particularly the Muslims. The debate of freedom of India was complemented with the debate of provincial autonomy and preservation of rights of minority groups in a post-colonial political setup. Failure to guarantee the demands of preservation of Muslims' rights by the major stakeholders, in the last pre-independence decade finally led to the demand for a complete separation. Thus, Pakistan emerged as an independent sovereign state comprising of majority Muslim regions in the East and West of India. One of the main issues that haunted political development in Pakistan surrounded the debate on the nature of the state and ideas of nation building. Therefore, it is pertinent to review the literature on the federal question before analysing the existing trends in the various federating units.

The existing literature on the federal question of the state identifies two schools of thought in the post-independence period, who contested the nature of political structure in the newly independent state of Pakistan; the federalists and the centralists. The federalists argued that Pakistan is an outcome of a minority's struggle for independence against a majority. Had the majority showed its willingness to accept the identity of minority Muslims of the sub-continent would have not been divided. Therefore, it is evident from history that suppression of subnational groups may lead them to look for the path of secession. Based upon this argument the federalist called for accommodation of sub-national identities and proposed a true federal structure in Pakistan.

The centralists refuted the argument on the grounds that empowerment of the sub-national identities may emerge as a challenge to national security and integrity of the state. They refused to accept the role of the ethnic and lingual identities in nation building. The centralist dominated the political system which led to the feeling of alienation among different ethno-lingual groups. The history of sub-continent was repeated in Pakistan within twenty-four years of its independence when refusal to accept Bengali identity led to separation of the East Pakistan in 1971 which became Bangladesh. Despite facing this shock of disintegration and endemic centrifugal tendencies in its smaller ethno-national groups, by and large, the managers of Pakistan failed to learn from its history. The centralist dominated the political structure throughout its history despite its claims of a federal state. The $18^{\text {th }}$ Amendment was a major breakthrough in its constitutional history which shifted the equilibrium towards federalists in Pakistan. Rabbani (2016), Adeney (2007), Bhattacharjee (2018), Ahmad (2010), Leys (1976), Newberg (1995) Cohen (2002), Jones (2002), Goodson 2001) have given detailed debates on federalist-centralist controversies in their works.

This paper is mainly divided into three sections. The first section deals with the methods applied and material used for analysis and discussion of this study. Second section is an overview of Pakistan's experimentation with the ideas of federalism. The third section discusses the ethnic composition of Pakistan as well as the causes responsible for ethnonational consciousness. The fourth section deliberates on societal perspectives on the accommodation and acceptance of sub-national identities beyond the centre-province debate and with a particular focus on the ethno-national movements. Majority of existing debates and literature revolve around the themes discussed in the second and third sections ignoring mostly the societal perspectives on the question of federalism in Pakistan. This paper has engaged the societal variable to paint a broader and comprehensive picture of the issues surrounding the question of federalism in Pakistan. 


\section{Research Methodology}

This study is qualitative in nature and mostly the published material is used as secondary data to substantiate arguments developed through careful observation of political events and academic and intellectual debates on the issue. A wide range of discussions in various academic circles and critical analysis of news reports were utilized to develop the broader framework of the study. A descriptive and analytical approach is adopted while explaining the key concepts and developing the links among these concepts. Arguments are deduced from the existing theoretical paradigms. For explaining societal perspective New Marxist and Critical Studies paradigms have been utilized. Background of the study is approached through people's history approach. Reliance on secondary sources is a limitation of this study because empirical data generation for this study required a lot of financial resources. Therefore, this hindrance was addressed by deducing, analysing, and critically evaluating the existing material in the form of research articles, official documents and books.

\section{Experimentation with Federal Ideas}

In the post-colonial period, the debate on constitution making mostly revolved around the question of weightage of the two wings in representation and power sharing as well as how to adjust and accommodate the smaller sub-national identities within western wing. After almost a decade of constitutional dilemma, backed by the issue of language and representation, Pakistan framed its first constitution in 1956.

\subsection{Federalism and the Constitution of $\mathbf{1 9 5 6}$}

Although the Constitution of 1956 emerged with the claim of federal character, yet the spirit of system was centralized. Ethnic diversity in West Pakistan was undermined with the implementation of the one-unit formula. The federal list in the Constitution consisted of sixty items from ninety-four items under the article 106. The concurrent list consisted of 19 items with enough room for the centralization of administrative and economic development system. The federal government had superseding powers in the field of national security, economic development and coordination among the provinces. Total membership of the National Assembly was 310 , out of which 150 were to be elected by each unit through popular vote. The seats were further divided on population basis in western unit consisting of Punjab, Sindh, Balochistan and NWFP (now Khyber Pakhtunkhwa). Ten seats were reserved for women based on an indirect election (Khan, 2001). Before holding the election, the parliament was dissolved, and the Constitution was abrogated within two years after its promulgation by Ayub Khan in 1958. He became the Commander-in-Chief from 1958-1962 without any constitutional apparatus and with overly centralized martial rule. In 1962, a new constitution was promulgated popularly known as One Man's Constitution.

\subsection{Federalism and the Constitution of 1962}

Ayub Khan ignored the recommendations of the Constitution Commission. The Commission recommended maximum autonomy for federating units and implementation of a federal form of government (Aziz, 1967). Ayub Khan wanted a strong centralized governmental apparatus. Though the Constitution of 1962 reserved federal structure with three lists i.e., provincial, concurrent and central list, yet extraordinary power of the President and role of civil-military bureaucracy in the political system made it over-centralized. This over centralization of the 
system led to emergence of centrifugal tendency in the East Pakistan where Sheikh Mujeeb of Awami League emerged as a major critic of the centralization of the system and demanded for maximum provincial autonomy. Anti-Ayub movement in the post 1965 War period ousted Ayub Khan from power and resulted in abrogation of the Constitution in 1969. General Yaya Khan, as new Chief Martial Law Administrator, abolished the one-unit plan before the election of 1970 (Qureshi, 1961).

The general elections of 1970 surprised the military elite when Awami League swept the polls and got all except only two seats in East Pakistan. The meeting of the National Assembly was delayed. Awami league contested election on six-point formula. This formula demanded for maximum provincial autonomy. Alleging Awami League of conspiring against the integrity of Pakistan the government launched the Operation Searchlight against Awami League. To restore law and order in the province, the military used its coercive power. Delaying tactics of Islamabad in convening the National Assembly session resulted in violent conflict in East Pakistan where thousands of Bengalis were murdered, a refugee crisis erupted and the situation culminated in the secession of East Pakistan. Thus, a federal arrangement with strong centre failed and resulted in the dismemberment of the state in 1971.

\subsection{Federalism and the Constitution of 1973}

A new constitution was promulgated in 1973 which replaced the Interim Constitution of 1971. The Constitution of 1973 was similar in character with the Constitutions of 1956 and 1962. Federal system was preserved. The principle of bicameralism was adopted this time and an upper and lower house were introduced as Senate and National Assembly, respectively. Representation in the upper house was based on equality basis while representation in the lower house was accorded the on the population basis. The Constitution of 1973 is distinguished from the previous two constitutions because it introduced Senate as an upper house with equal representation to all federating units (Talbot, 1990). Despite the guarantees in the formal structure and claims of establishing a true federation some critics of this constitution argued that the issue of language and ethnicity were not addressed properly. Punjab enjoyed the absolute majority in National Assembly whereas Urdu became the only national language (Adeney, 2007).

The federal structure was established in 1973 Constitution having two lists i.e., Federal List and Concurrent List. There were 67 subjects in Federal List, while Concurrent List empowered the provincial legislatures to legislate on the subjects listed in it. In case of a conflict between the centre and province, the decision of the centre would supersede. The Council of Common Interest (CCI) was established to strengthen the spirit of the federation. The Council was composed of chief ministers of provinces and an equal number of federal government representatives. It was to be appointed by the President. The council has the authority to hear complaints against centre and supposed to make policies related to oil and gas, railway, industrial development and electricity (Ahmad et al., 2007).

On the day of promulgation of the Constitution on August 14, 1973, the prime minister Zulfiqar Ali Bhutto made a significant speech. He declared that the days of violence in politics and the coups were ended. Bhutto's government wanted strong central arrangements, which created the feeling of disgruntlement in Pashtun and Baluch segments of the society. Only after the two days of the promulgation of the Constitution, the Governor and the Chief Minister of Baluchistan were arrested on the basis of corruption and seditious activities along with a 
member of the National Assembly. National Awami Party (NAP) was declared as an unlawful organization and its government was dissolved on the basis of incapability. The activities of NAP were declared as damaging to integrity and sovereignty of Pakistan. All this led to serious dissatisfaction among the different ethnic groups. When the resistance of the opposition led to worsening of law and order situation, General Ziaul Haq took the advantage of time and suspended the Constitution for eight years (Khan et al., 2017).

\subsubsection{Eighth Amendment to 1973 Constitution}

During the suspension of the Constitution, the political system was converted into a unitary form of government. Many presidential ordinances were issued and later $8^{\text {th }}$ Constitutional Amendment was introduced to legitimize the coup and attack the true federal nature of the Constitution. The order which restored the Constitution is known as the Revival of the Constitution Order 1973 (RCO). It was passed on $2^{\text {nd }}$ March 1985 and sixty-five articles of the Constitution were amended, added, omitted, submitted and modified. Through this amendment, presidential office got more powers than it enjoyed under the original Constitution of 1973. The president now had the power to dissolve National Assembly (Ziring, 1980). The structure of government remained federal theoretically, even after the amendment. It even enhanced the legislative powers, representation of provinces (14-19) and tenure of members (4-6 years) in the Senate. Senate had equal representation from all provinces and a representation from erstwhile FATA (Khan, 2010). The seats of Senate were increased to eighty-seven from sixty-three and five seats were reserved for technocrats and professionals or ulema. The reserved seats for women were also increased (Jetly, 2009). The amendment empowered the small provinces in the key decision-making maters.

\subsubsection{Seventeenth Amendment to 1973 Constitution}

Pakistan experienced a new martial law on October 12, 1999. For national cohesion and to strengthen the federation, General Musharraf presented a seven points formula during his speech on October 13, 1999. To achieve the agenda set by General Musharraf in his first speech National Reconstruction Bureau (NRB) was established. NRB was chaired by a retired lieutenant general. It started working on a constitutional package of amendments in 'great secrecy' (Najam, 2009). On August 21, 2002 a new Legal Framework Order (LFO) was implemented with a new devolution of power plan. The critics of LFO termed it against the spirit of the Constitution of 1973. The local government bill was criticized for curtailing the powers of provincial governments. $17^{\text {th }}$ amendment was passed from the parliament when general elections took place in February 2002. After extensive political debates and political bargaining in December 2003, especially with Muttahida Majlis-e-Amal (MMA), an alliance of religious political parties, it was finally passed by the parliament. President was once again empowered to dissolve the parliament. Yet Supreme Court had the authority to review the decision of the President.

\subsubsection{Eighteenth Amendment to 1973 Constitution}

The National Assembly of Pakistan passed the $18^{\text {th }}$ Constitutional Amendment on April 8, 2010. The same was also passed by the Senate on April 15, 2010 and the President of Pakistan granted his assent on $19^{\text {th }}$ April 2010. The amendment curtailed the powers of the president to dissolve the parliament. It is stated that the Amendment reinstated the parliamentary spirit of the Constitution. For the first time in the history of Pakistan, the president signed a bill willingly 
that truncated his powers. The $18^{\text {th }}$ Amendment also enhanced the independence of judiciary as the Judicial Commission was empowered to appoint the judges of the Supreme Court. The president would not introduce an emergency in the provinces without the advice of the concerned chief minister and would not have the power to appoint the Chief Election Commissioner. The $18^{\text {th }}$ Constitutional Amendment was a landmark achievement in ensuring a federal character of the state. Nonetheless, the $18^{\text {th }}$ Amendment revived the following principles of Constitution of 1973:

- Federal parliamentary system of government was restored.

- Prime Minister became the Chief Executive.

- President became a symbolic head, bound by advice of the prime minister in all matters.

- The name of NWFP was changed to Khyber Pakhtunkhwa.

- The restriction on contesting for the third tenure as a prime minister was removed.

An overview of how the federal question of the state has been dealt in during the constitutional development in Pakistan reflects that over the years, the state narrative on acceptance and accommodation of the sub-national entities has transformed to a greater extent. In the post $18^{\text {th }}$ Amendment period, more stress has been given on the federal spirit and the federalists have started to dominate these debates. Despite these developments at the state level, it is pertinent to understand the societal perspective on federalism in Pakistan. The upcoming discussion focuses primarily into the investigation of widespread perceptions of different sub-national groups. The unit of analysis for understanding these perceptions is not the larger body of these groups due to lack of resources which could have been a better and more accurate parameter. To deal with this limitation, the political representation of these groups, in the form of political parties, and research studies of the academicians have been taken as an evidence to substantiate the arguments.

\section{Ethnic Composition, Mobilisation and Perspectives on Federalism in Pakistan}

Management of the ethnic diversity has remained a big issue in Pakistan. Failure to cope with this issue led to dismemberment of its Eastern Wing in 1971. The incident of 1971 gave impetus to many similar movements in West Pakistan like Baloch uprisings (1973-77, and 2002 till date); Pashtun regionalism (1970s); Sindhi regionalism (1980s); and the disturbances created by Muhajirs on ethnic lines (1990s). Ethnic movements around the globe and particularly in post-colonial societies have significantly attracted the attention of the social scientists. Firsthand studies of developing states show that there are some links between political institutions and the rise of ethnic mobilisation. Lijphart, for example, maintains that "democracy is possible in deeply divided societies but only if their type of democracy is consensual. Certain European countries have managed diversity through consociationalism, but overall performance of such arrangements remains mixed" (Andeweg, 2000).

McGarry (2006) argues that "Federalism is usually not enough: consociational practices, particularly at the federal level, are highly important to the success of multi-national federalism". Adeney (2007) also suggests some degree of consociationalism and representation in the decision-making institutions in the federal politics. She explains that though federal system provides some degree of autonomy, but in the decision-making process it does not provide security at the national level. She concludes that in the multi-ethnic states, the federalist arrangements facilitate successful accommodation'. However, as federations may be 
different, therefore, different states have different forms of governance. Therefore, different states will have different capacities to manage the ethnic diversity according to their federal structure (Mushtaq, 2009).

The Pakistani federation failed to resolve the problem of ethnic differences and it became the first post-colonial state, in the sub-continent, which lost one wing in 1971, i.e., East Pakistan. Even now Pakistan is one of the world's most ethnically and linguistically heterogeneous states. Throughout Pakistan's history, different ethnic groups have challenged the centralization drive of the federal governments at different times. One significant factor responsible for political instability in the country is mainly due to the mobilization on ethnic lines. To manage the diversity in Pakistan, numerous alternate strategies have been proposed over the period of time and have been practices as well.

The proposed solutions include confederation, consociationalism, power-sharing, and reorganisation of provincial boundaries. Some have given an interesting solution of including the socially and economically marginalized communities and other excluded groups in the political system of Pakistan. However, there still exist some arguments asking for bold policies to refigure the federal structure of Pakistan that can accommodate the ethnic diversity. Kennedy (1993) proposes to "redesign territorial boundaries of the constituent units to make them accord more closely with the ethnic landscape of the state" to manage diversity. Furthermore, he suggests more devolution of power and authority by central government for the federating units. He believes that in theory there is federal system in Pakistan however in practice it works as a unitary system. It is argued that "the more a formal federal system operates in practice as a unitary system, the less is system's capacity to accommodate ethnic and territorial cleavages" (Mushtaq, 2009).

There are many ethno-lingual groups living in Pakistan. Punjabis are living in Punjab, Sindhis in Sindh, Balochis in Baluchistan and Pashtuns in Khyber Pakhtunkhwa. However, there are many linguistic and ethnic divisions within each of these provinces. On the basis of ethnicity, Sindh is the most diverse province. Mohajirs are in majority in the urban Sindh. Sindhis, who are known as the sons of the soil - are in rural Sindh. Punjabis, Pashtuns and Baloch also live in Sindh. Balochistan is the home province of Baluchis and Pashtuns. A large number of Sindhis and Siraikies also live in Balochistan. Punjab and Khyber Pakhtunkhwa are heterogeneous provinces. A large number of Siraiki speaking population live in the southern part of Punjab. Similarly, besides Pashtuns, a large number of Hindko and Siraiki speaking people live in Khyber Pakhtunkhwa (Amin, 1998).

Pakistan has been facing the problem of ethnic nationalism since its inception. The nationalist orientation of different ethnicities like Bengali, Pashtun, Sindhi, and Baloch has created many problems for the state at various times. Mohajirs have been mobilizing on the ethnic lines for the protection of their interests since 1980s. Mohajirs are Urdu speaking who migrated to Pakistan in 1947 from India and inhabited mostly in urban Sindh (Harrison, 1981). The Seraiki speaking community in the southern Punjab has also been mobilizing on ethnic lines. Therefore, excluding Punjabis, which is the majority as well as politically dominant group; all the small sub-national groups asserted that they have been marginalized due to centralization of the political power.

Punjab is the largest populated province of Pakistan after the secession of East Pakistan in 1971. It is relatively a developed province. Punjabis have dominated the armed forces and civil 
bureaucracy. It has been perceived as Punjabization of state institutions by the smaller units. The era of the Military rulers has also been equated with Punjabi domination. The core of ethno-national perception in Pakistan is that the people of Punjab have dominated the politics of the country. It is also argued that as Punjab dominates in all the institutions of the state, therefore, it has 'never pressed for greater autonomy'.

\subsection{Separation of East Pakistan}

At the time of partition of India in 1947, the Muslims of Bengal decided to join Pakistan. The Non-Muslims members of Bengal Assembly were in favour of the division of Bengal, so it was divided. The Hindu majority Bengal was included in India while the Muslim majority Bengal joined Pakistan. Despite division, Bengal remained the most populous province of Pakistan. Its population was more than the combined population of the western Pakistan including the princely states. When Pakistan came into being it had no constitution of its own. Therefore, with some amendments, it adopted All India Act 1935 as an interim constitution of Pakistan. The Constituent Assembly of Pakistan was given the responsibility to frame a new constitution for the country. Debates over the constitutional issues in the Constituent Assembly resulted into distrust between the members from eastern and the western wings of Pakistan. Bengalis had concerns over some issues - such as the national language of the country and representation of the provinces in National Assembly - during the constitution making process (Ali, 1996). Unlike their counterparts in Punjab, the East Pakistanis demanded autonomy and decentralisation of political power.

The East Pakistan's grievances were politicized whereas the 'central government was unable or unwilling to devolve the authority'. Eventually, this led to the autonomous and separatist demands and at last East Pakistan became Bangladesh in 1971 (Awan, 1985). Samad (2007) summarizes the grievances and argues that, "from the centre, the exclusion of Bengalis, the tightening grip of the central government at Karachi, which was the country's political and commercial hub, over East Pakistan and the language controversy were not handled sensitively. There was also a growing sense of deprivation which pushed the Eastern Wing towards separatism". He also observed that it was the power-structure at federal level that resulted in the marginalisation of East Pakistan's elites. Consequently, this sense of relative deprivation led to the emergence of Bangladesh as a sovereign state in 1971.

\subsection{The Pashtun Separatism}

The Pashtuns of Khyber Pakhtunkhwa had strong feelings of distinctiveness. The 'Khudai Khidmatgar' (servants of God) movement of Bacha Khan, who was a Pashtun nationalist, had a popular rural foundation in predominantly Pashtuns districts of the Khyber Pakhtunkhwa. The Khudai Khidmatgar organization was successful in winning the provincial elections of 1937 as well as 1946. Consequently, they formed provincial governments in the then NWFP (now Khyber Pakhtunkhwa). Pashtun nationalists refused to buy the Two Nation Theory of All India Muslim League. They had been struggling for complete independence of India before 1930. They also showed resistance when the British decided to include former NWFP in Pakistan. They were not ready to join Pakistan. They wanted a separate state for Pashtuns. They tried to persuade the Governor General, Lord Mount Batten, for a third option, i.e., an autonomous state of their own choice. The Governor General rejected their demand, for the third option. As a result, they boycotted the referendum. Consequently, All India Muslim league got majority in the referendum in favour of Pakistan (Siddique, 2014). 
The word Pakhtunistan (Pashtunistan) has different meanings for different people, as it ranged from the demand for the creation of a new state integrating Pathan regions on both sides of the Pakistan-Afghanistan border to mere change of nomenclature for the NWFP (now Khyber Pakhtunkhwa). When Pakistan came into being in 1947, the Pashtuns said that by 'Pashtunistan' they meant regional autonomy of Khyber Pakhtunkhwa. In the general elections of 1970, Pakistan Peoples Party (PPP) got victory in Sindh and Punjab. JUI and NAP succeeded in winning majority seats in Baluchistan and former NWFP. From April 1972 to February 1973, there an accord was signed between the Pakhtuns and the ruling party of Z. A. Bhutto for power sharing. Because of that accord, the Pashtuns left the Pashtunistan agenda. In the tripartite agreement, they agreed to give due respect to each other's mandate. "Our demand for Pashtunistan has been fulfilled" was declared by Abdul Ghaffar Khan who hitherto had been demanding for a separate autonomous homeland for Pashtuns (Siddique, 2014, 20-45).

On a question whether he was, 'a Muslim, a Pakistani or a Pashtun first', Wali Khan claimed that he was, "a six thousand years old Pashtun, a thousand years old Muslim and 27 years old Pakistani". Meanwhile, due to the migration of Pashtuns into urban centres of Punjab and Karachi they 'dominated the privately-owned transport sector' and also got employment opportunities in other sectors. They got a share in the country's power-structure. A large number of Pashtuns are also co-opted in the Pakistan Armed Forces. The majority of Pashtun officials and soldiers who got jobs belong to those areas that had traditionally been in the grip of the Pashtunistan movement. The Pashtunistan movement declined due the accommodation and incorporation of the Pashtuns in the power-structure. Now it is argued by most of the people that 'Pashtun Movement had died'. But conversely, the evidences show that Awami National Party (ANP) has historically been successful in securing electoral support from Pashtun areas to a greater extent.

In the Post 9/11 period, the war against terrorism has changed the political dynamics of the region. Talibanization of the region led to terrorist activities and violence. Despite this, ANP, a relatively secular Pashtun nationalist party, emerged as a single largest party in Khyber Pakhtunkhwa in 2008 elections. The $18^{\text {th }}$ Constitutional Amendment fulfilled their years old demand of renaming NWFP as Khyber Pakhtunkhwa. Elections in 2013 changed the political dynamics of Khyber Pakhtunkhwa where a Punjabi led Pakistan Tehreel-i-Insaf (PTI) defeated ANP. According to some critics, Pashtun nationalism has lost its spirit in the post renaming period and people have started thinking on other issues divorcing identity issues. Recently, racial profiling of Pashtuns in Punjab helped the re-emergence of Pashtun nationalist feelings. It depends now on the ability of ANP, to what extent, it can exploit the situation and translate the identity consciousness into electoral victory and demands for more provincial autonomy. Emergence of Pashtun Tahafuz Movement (PTM) as a representative of Pashtun youth of the erstwhile FATA region has also damaged the popularity of ANP. The PTM has given a new impetus to the Pashtun nationalism in Southern Khyber Pakhtunkhwa.

\subsection{Sindhi Regionalism}

Sindh was separated from Bombay in 1936 and restored its provincial status. In 1937, All India Muslim League was unable to find any candidate in Sind to contest the election though it was a Muslim majority province. The members of Sindh Assembly, Sheikh Abdul Majeed and G. M. Sayed joined All India Muslim League in 1938 and in the same year a resolution for a separate homeland for the Muslims of sub-continent was passed from Sindh Assembly (Qureshi, 1961). A resolution was also passed in Sindh assembly in support of Lahore 
resolution of 1940 on March 3, 1943. Subsequently, by a vote of 33 to 20, Sindh Assembly decided to join Pakistan on the eve of independence (Khan, 2001).

Ethnically, Sindh was not a homogeneous region before the creation of Pakistan. There was no significant hatred among Sindhis against the Punjabi and Baloch settlers. The people from other areas also adopted Sindhi language and they were 'integrated into the Sindhi culture'. After independence, the Sindhis were alarmed by the influx of 'millions of Muhajirs in 1947. The Muhajirs were industrious, well-educated and resourceful. The policy of central government to settle Muhajirs in Sindh was rejected by the government of Sindh. This led to the dismissal of the then Chief Minister Sindh, Ayub Khuhro on recommendation of central government by the provincial governor. The growing number of settlers in urban Sindh changed the demographic, economic and political balance of Sindh (Khan, 2002). The people of Sindh had many grievances. These include the influx of refugees, the imposition of one unit-scheme (under this scheme all the provinces of the West Pakistan were united to form one unit called West Pakistan) and separation of Karachi from Sindh as a federal territory. They had also reservations on the allotment of lands to the non-Sindhi people. The under representation of Sindhis in the civil and the military bureaucracy was another point of dissatisfaction among Sindhis (Khan, 2002).

Under the One Unit scheme, the Sindhis were even more side-lined. The language of the Sindhis was suppressed. A large number of Sindhi medium schools were closed. 'Sindhi newspapers were denied advertisements from the government and Sindhi writers were discouraged. Sindhi publications were widely censored and suppressed. This policy on the part of the federal government created hatred among the people of Sindh against the centre. Bhutto, cleverly, used the 'jingles recited by Sindhi nationalists' in the 1970 election campaign and became victorious in Sindh (Talbot, 1990). In West Pakistan, Bhutto won the election and came into power after the dismemberment of Pakistan in 1971.

When Bhutto came into power, the national integration of the Sindhis became easier. Pakistan Peoples Party (PPP) formed governments at the centre and in Punjab and Sindh. Bhutto made such policies, that solved many problems of the people of Sindh. Many of his policies were in favour of Sindhis. For instance, he introduced the quota system for distribution of government jobs and employment in educational institutions in urban-rural (40\%-60\%) regions of Sind, which gave advantage to the rural Sindhis. However, this scheme went against the interest of Muhajirs. Bhutto's government was dismissed in 1977 and finally he was executed through Punjabi dominated Supreme Court in a judicial trial in 1979. This act re-created nationalist feelings in the rural Sind. This unrest turned into sporadic violence in interior Sindh. Some people argue that the main purpose of this movement was more to do with economic issues and to get the political share in decision-making process. However, the first pro-Sindhi government was removed. It was replaced by an army rule which was Punjabi-Pashtun dominated. It fuelled ethnic bitterness in the province (Khan, 2002).

After the assassination of General Zia-ul Haq, the Benazir Bhutto led Pakistan Peoples Party (PPP) came into power. She was able to attract the nationalist Sindhis whose feelings were wounded during General Zia regime. Most of the PPP supporters were from rural Sindh. There were many other nationalists in Sindh, but they were unable to compete with PPP. These parties were able only to get the support of 5 to 6 percent people of the rural Sindh. Nevertheless, 'the PPP always advocated the cause of Sindhi nationalism at the provincial level. All the Sindhis had strong nationalistic feelings but they were not properly organized. Their struggle was 
against the interference of the central government (Punjabi dominated) in the affairs of the Sindh province (Rehman et al., 2017). The Sindhi nationalism resurfaced after the assassination of Benazir Bhutto at Rawalpindi (a city of Punjab) during the election campaign of 2008 Election. However, Asif Ali Zardari (who was the husband of Mrs Bhutto) and Nawaz Sharif (who was the most popular leader of Punjab) have successfully managed the issue. Nonetheless, it can be argued that Pakistan Peoples Party played a role of neutralizing centrifugal forces in Sindh.

\subsection{Mohajir Identity Politics}

In the early years of Pakistan, the Mohajirs and Punjabis dominated the politics of the country. But Punjabis continued to be over-represented in the administration and army. They dominated the political decision making and bureaucracy. The Mohajirs had a privileged status in the country. They identified themselves with the Islamic ideology and Pakistani state. Their position gave them a chance to remain hostile towards regional ethnic movements. After the murder of Liaqat Ali Khan, Punjabis became dominant in the politics of the country. In addition, in 1958 General Ayub Khan imposed Martial Law in the country (Adeney, 2007). It produced a new Pathan-Punjabi alliance and the Muhajirs who considered themselves as the makers of Pakistan were pushed to the background.

The Mohajirs were further marginalized during Bhutto era. Sindh Assembly passed its first bill regarding the language in 1972. Sindhi language was made compulsory (for official purposes) under this law. However, the Mohajir community looked this move as a biased step and an encroachment on their right to employment and resorted to mass protests in Karachi. From 1973 to 1986, the Mohajir's representation declined in overall official positions from $30.1 \%$ to $18.2 \%$ and from $33.5 \%$ to $18.3 \%$ in senior positions. Slowly and gradually, the "ethnic composition of the military-bureaucracy shifted even further in favour of Pashtuns and Punjabis at the expenses of Mohajirs. A sense of deprivation started to grow in the community of the later and it gave rise to Muhajir identity politics (Gilani et al., 2017).

The rise of Mohajir Qaumi Movement (MQM) in 1984 in urban Sindh was quite dramatic and sudden. Its leaders belonged to the strata of community, which experienced unemployment and was from the middle class. MQM had been spreading its message in urban Sindh since late 1980s (Afzal, 1998). It got tremendous support in Hyderabad and Karachi, major urban centres in Sindh. MQM formed alliances at different times with governments of Nawaz Sharif and Benazir Bhutto in Islamabad and Karachi. Another feature of this Muhajir movement was its militant character, which led to two military operations in urban Sindh. This violence resulted in around 9000 casualties from 1985-1998 (Gilani et al., 2017).

\subsection{Baloch Nationalism}

The Pashtun majority areas, the Bugti-Marri tribal areas, Kalat state and states of Kharan, Makran and Lasbella including British Balochistan were parts of Balochistan in the colonial period. Mir Ahmad Yar Khan who was the ruler of Kalat state, declared independence on August 15, 1947, a day after Pakistan was formally created. Both houses of the Kalat Assembly had recommended this decision and rejected unification with Pakistan. However, the Khan of Kalat had to sign the papers of accession formally joining Pakistan. The Baloch nationalists resisted the decision. An armed struggle started by Prince Abdul Karim in Jhalawana area of Kalat (Ahmed, 1990). 
When the One Unit plan was implemented, Mir Noroz Khan Zahri started a movement against this centralising policy of the federal government. He fought the case of Baloch nationalists enthusiastically but finally agreed to surrender and was offered a safe exit by the army. However, he was arrested with his companions and later died in jail. To get the status of a province, Balochistan had to wait for a long time. Balochistan got the provincial status on the dissolution of one-unit scheme in 1970. The Baloch and Pashtun nationalists contested the first general elections of the Pakistani history in 1970 under the banner of National Awami Party (NAP). The Baloch nationalists done well and were able to form their government in Balochistan. However, the government of Attaullah Mengal was dismissed in February 1973 on the allegations of lawlessness and failure to comply with the directives of central government. The dismissal sparked a sharp conflict of nationalists with the centre. This led to a revolt that remained at its peak from 1973 to 1977 . The Baloch army was composed of 55,000 Baloch fighters, including 11,500 organized combatants. They fought against 80,000 regular military forces that were called to suppress the Baloch resistance. The insurgency caused loss of at least 10,000 lives from both sides according to the media reports.

After military coup of 1977 , General Zia-ul Haq adopted relatively a softer attitude towards the Baloch by releasing the detained Baloch leaders. He announced a general amnesty for the nationalist guerrillas. However, he refused to withdraw the military troops from Balochistan. No compensation was paid to the sufferers of military action in Balochistan. Though the Baloch were marginalized and suppressed, even then the feelings of nationalism in Balochistan seemed subsided due to the representative democracy during 1990s (Najam, 2009). However, after military takeover of 1999, another episode of insurgency challenged the writ of the central government. Although, leaders and regional parties are still trying to obtain economic, social and political rights within a federal parliamentary framework in a democratic way, the militants have picked up the guns. Mollifying efforts and military action remained simultaneously intact in Balochistan. The parliamentary committee was unable to implement its approvals because of the involvement of the military in the case. Personal resistance of Nawab Aknar Bugti (a Baloch leader who was previously the governor and then chief minister of Balochistan) and his subsequent assassination made the case more problematic.

\subsection{Siraiki Movement}

Punjab province can be divided into three well-known groups or regions on the basis of language and geography. First, the central Punjab, which is mostly Punjabi speaking; second, the northern Punjab, which is Pothowhari speaking; and third, the southern Punjab dominated by Siraiki speaking. The Punjabi ruling group is made up of civil-military officers, businessmen and administrators from the central and the northern Punjab. The central and northern Punjab is "jointly" called as the 'Upper Punjab' by the Siraikis of the southern Punjab. Nonetheless, The southern Punjab is a relatively marginalized and poorer region. The Siraiki-speaking regions have made a conscious and clear attempt to aloof themselves from the overriding groups in Punjab. The Siraiki identity is 'still very new' marvel, and those people who are 'known as Siraiki speaking' had a different history. Bahawalpur was a princely state which became part of Punjab in 1970. The language of the majority of the people in the region was 'Riyasti'. Multan was a part of Sindh and the language of this area was Multani. The people of Dera Ghazi Khan and the surrounding areas had a different language. That language is known as 'Derewal' and have historically 'tended towards Baloch identity (Khan, 2010). The evolution of Siraiki identity took place, more or less, at the same time and in the same manner in its twin centres of Multan and Bahawalpur. 
Different types of cultural and literary organizations came into being in 1960s and early 1970s but the movement, mostly, remained cultural in character. The Seraiki movement remained away from the interrelated political mobilization. After the dissolution of one-unit scheme, some voices were raised in favour of a separate Siraiki province. The Siraiki speaking people were not supporting the Siraiki political parties. Although, they tried their best to get the support of the people by stressing on their demands and under-representation of the Seraiki speaking people, but they were unable to get support of the majority in various elections. The upper class was less interested because they had strong footings in the mainstream political parties of the Punjabi ruling class (Asif et al., 2020).

\section{Conclusion}

The survey of ethno-nationalist movements in Pakistan shows that it was the policy of centralization on the part of the central government, which was responsible for a growing sense of Punjabi supremacy and marginality in other provinces and ethnic groups of the federation. The Punjabi dominated federal authorities interfered in provincial governments and even dismissed many over the course of history leading to gross mistrust against the central government among the federating units. Although, all the three constitutions promised for the establishment of the federal polity in Pakistan yet these promises were never fulfilled. Pakistan seems a typical quasi federal polity from political and constitutional analysis of her history. This study concludes that over-centralization of power and authority in the centre has led to two parallel developments. On one hand, it allowed federating units to demand for decentralization and provincial autonomy, while on the other, different ethno-lingual identity groups within these units have aligned and organized themselves against the dominant groups of their respective units. The demands of provinces were met to a greater extent with the passage of $18^{\text {th }}$ Constitutional Amendment but voice of smaller identities within these units still is unheard. Only through decentralization and devolution, the emerging issues of Pakistani federalism could be resolved.

\section{References}

Adeney, K, (2012). A step towards inclusive federalism in Pakistan? the politics of the 18th Amendment. The Journal of Federalism, 42(4): 539-565. https://doi.org/10.2307/41682902

Adeney, K. (2007). Federalism and ethnic conflict regulation in India and Pakistan (1 ${ }^{\text {st }}$ Ed.). Palgrave Macmillan.

Ahmad, I., Mustafa, U., \& Khalid, M. (2007). National Finance Commission Awards in Pakistan: A Historical Perspective. MPRA Paper 5249, University Library of Munich, Germany. https://ideas.repec.org/p/pra/mprapa/5249.html

Ahmed, R. (2010). The endemic crises of federalism in Pakistan. Lahore Journal of Economics, 15(SE),

15-31.

https://lahoreschoolofeconomics.edu.pk/economicsjournal/journals/volume $\% 2015 / \mathrm{i}$ ssue\%20sp/02\%20raza\%20ahmad\%20edited\%20ttc\%2011-10-10.pdf

Ahmed, S. J. (1990). Federalism in Pakistan: a constitutional study. Pakistan Study Centre, University of Karachi.

Ali, M. (1996). Politics of federalism in Pakistan. Royal Book.

Amin, T. (1998). Ethno national movements of Pakistan. Institute of Policy Studies. https://www.ips.org.pk/ethno-national-movements-of-pakistan/ 
Andeweg, B. R. (2000). Consociational democracy. Annual Review of Political Science, 3, 509-536. https://doi.org/10.1146/annurev.polisci.3.1.509

Asif, M., Naazer, M. A., \& Ahmad, R. (2020). Saraiki province movement in Punjab: causes, prospects, and challenges. Liberal Arts \& Social Sciences International Journal (LASSIJ), 3(2), 35-47. https://doi.org/10.47264/idea.lassij/3.2.5

Awan, A. B. (1985). Baluchistan historical and political process. New Century.

Aziz, K. K. (1967). Making of Pakistan: a study in nationalism. ( $3^{\text {rd }}$ ed.). Sang-e-Meel.

Bhattacharjee, D. (2018). Provincial autonomy, decolonization, war and independence. South Asian History and Culture, 9(2), 159-180. https://doi.org/10.1080/19472498.2018.1446795

Cohen, S. P. (2002). The nation and the state of Pakistan. The Washington Quarterly, 25(3). 109-122. https://doi.org/10.1162/01636600260046271

Gilani, S. M. S., Salim, A., \& Khan, N. U. (2017). The role of Muttahida Qaumi Movement in Sindhi-Muhajir controversy. Liberal Arts \& Social Sciences International Journal (LASSIJ), 1(1), 71-82. https://doi.org/10.47264/idea.lassij/1.1.8

Goodson, L. P. (2001). Afghanistan's endless war: state failure, regional politics, and the rise of the Taliban. University of Washington.

Harrison, S. S. (1981). In Afghanistan's shadow: Baluch nationalism, and Soviet temptations. Carnegie Endowment for International Peace.

Jetly, R. (2009). Resurgence of the Baloch movement in Pakistan: Emerging perspectives and challenges. In Rajshree Jetly (ed.), Pakistan in Regional and Global Politics. Routledge.

Jones, B. O. (2002). Pakistan: eye of the storm. Yale University.

Kennedy, C. H. (1993). Managing ethnic conflicts: the case of Pakistan. Regional and Federal Studies, 3(1), 123-143. https://doi.org/10.1080/13597569308420861

Khan, A. (2002). Pakistan's Sindhi Ethnic Nationalism. Asian Survey, 42(2), 213-229. https://doi.org/10.1525/as.2002.42.2.213

Khan, A., Khan, T. M., Rehman, A. U. (2017). Government-opposition relations amidst the provincial autonomy during Bhutto regime. Journal of the Research Society of Pakistan, 54(2), 41-52. http://pu.edu.pk/images/journal/history/PDF-FILES/04Paper_54_2_17.pdf

Khan, H. (2001). Constitutional and political history of Pakistan. Oxford University.

Khan, M. (2010). Ethnic federalism in Pakistan: groups, federal structure \& construction of ethno-linguistic identity. Lahore mimeographed paper.

McGarry, J., Keating, M., and Moore, M. (2006). Introduction: European Integration and the Nationalities Question. In J. McGarry and M. Keating (eds). European Integration and the Nationalities Question. Routledge.

Mushtaq, M. (2009). Managing ethnic diversity and federalism in Pakistan. European Journal of Scientific Research, 33(2), 279-294. https://www.researchgate.net/publication/251238667_managing_ethnic_diversity_a nd_federalism_in_pakistan.

Najam, A. (2009, November 24). Full Text of the Balochistan Package: Is it enough? https://pakistaniat.com/2009/11/24/balochistan-package/

Naazer, M. A., Mahmood, A., \& Ashfaq, S. (2017). An analysis of political rights situation during Musharraf regime (1999-2004). Liberal Arts \& Social Sciences International Journal (LASSIJ), 1(1), 21-31. https://doi.org/10.47264/idea.lassij/1.1.3

Newberg, P. R. (1995). Judging the state: courts and constitutional politics in Pakistan ( $1^{\text {st }}$ Ed.). University of Cambridge. 
Qureshi, I. H. (1961). The struggle for Pakistan. University of Karachi.

Rabbani, R. (2016). A biography of Pakistani federalism: unity in diversity. Leo Books.

Rehman, A. U., Khan, A., Khan, B. (2017). Government-opposition relations during Benazir Bhutto's rule. Liberal Arts \& Social Sciences International Journal (LASSIJ), 1(2), 24-33. https://doi.org/10.47264/idea.lassij/1.2.3

Samad Y. (2007). Pakistan: From minority rights to majoritarian, In Gyanendra, P. \& Samad, Y. (ed.). Fault lines of Nationhood. Roli Books.

Siddique, A. (2014). The Pashtun question the unresolved key to the future of Pakistan and Afghanistan. Oxford University.

Talbot, I. (1990). Provincial politics and the Pakistan Movement. Oxford University.

Leys, C. (1976). The overdeveloped post-colonial state: a re-evaluation. Review of African Political Economy, 5, 39-48. https://doi.org/10.1080/03056248108703276

Ziring, L. (1980). Pakistan: the enigma of political development. W. Dawson \& Sons. 